\section{Список литературы:}

1. Известия Российской академии наук. VI серия. Петроград, 1918. № 14. С. 1387-1399.

2. «Мы не нищие...»: к истории 200-летнего юбилея Российской Академии наук (из дневника Е.Г. Ольденбурга) / Публ. М.Ю. Сорокиной // Источник. 1999. № 6. С. 28-41.

3. Черказьянова И.В. Юбилеи Академии наук как фактор развития историографии в советский и современный период / Институт истории естествознания и техники им. С.И. Вавилова. Годичная конференция, 2009. М.: Анонс Медиа, 2009. С. 660-662.

4. Собрание узаконений и распоряжений Рабочего и Крестьянского правительства РСФСР. 1925. № 48. Ст. 363.

5. Молас Б.Н. Юбилейные дни // Научный работник. 1925. № 3. С. 43-47.
6. Национальный архив Республики Карелия.

Ф. Р-131. Оп. 1. Д. 57. Л. 1-12.

7. Карелия: энциклопедия: в 3 т. / гл. ред. А.Ф. Титов. Т. 1: А-Й. Петрозаводск: ИД «ПетроПресс», 2007. С. 361-362.

8. Исаченко Б.Л. Заметки о 200-летнем юбилее Академии наук Союза ССР 1725-1925. Машинопись // Архив РАН. Ф. 583. Оп. 1. Д. 9. Л. 1-2.

9. Иванов П.В. Педагогические основы школьного краеведения. Петрозаводск, 1966. 181 с.

10. Интервью С.О. Шмидта: «Речь идет о сохранении России» // Наше наследие. 2005. № 74.

Публикация подготовлена при поддержке Комплексной программы УрО РАН «Исследователи Севера России: биографика и научное наследие» (проект 18-6-6-2).

\title{
«...INEXTINGUISHABLE SPARK OF LOVE FOR SCIENCE APPEARED IN ME DURING THE ANNIVERSARY OF THE ACADEMY...» (THE MEMORIES OF P.V. IVANOV - YOUNG PARTICIPANT OF THE 200TH ANNIVERSARY OF THE RUSSIAN ACADEMY OF SCIENCES)
} (C) 2018

\author{
Brovina Alexandra Alexandrovna, candidate of historical sciences, \\ head of Humanities Interdisciplinary Studies Department \\ Egorova Svetlana Lvovna, candidate of historical sciences, \\ senior researcher of Humanities Interdisciplinary Studies Department \\ Komi Scientific Center of Ural Branch of Russian Academy of Sciences (Syktyvkar, Russian Federation)
}

Abstract. The paper is devoted to one of the iconic pages in the history of academic science - the $200^{\text {th }}$ anniversary of the USSR Academy of Sciences. A broad program of the «science holiday» on an international scale with the invitation of foreign scientists, pointed to the scientific and political significance of the event, both to raise the prestige of the Academy of Sciences, and to demonstrate to the international community the loyalty of the scientific elite to the new government. Researchers repeatedly turned to the analysis of this event and stressed its importance. However, on the eve of the next anniversary, it is interesting to show this event from an unofficial position, attracting sources of personal origin. The paper focuses on the unpublished memoirs of Pavel Vladimirovich Ivanov (19061990), scientist-teacher, doctor of pedagogical sciences, professor, honored teacher of the Karelian ASSR. In 1925 he as a young local historian from the city of Soligalich of the Kostroma province became a participant of the academic celebrations. The impressions of this event predetermined his future destiny and choice of profession. P.V. Ivanov having traveled from a pupil of a rural school, keen on local lore studies, to a schoolteacher, and then a university professor, laid down in his students - future teachers - the idea to raise the pupils' interest, love and desire for young naturalists', local lore, scientific and research work.

Keywords: history of Russian Academy of Sciences; jubilee celebrations; collective memory; unpublished memories; scientist-teacher; professor Pavel Vladimirovich Ivanov; local lore, scientific and research work; education of students; Soligalich of Kostroma province; National Archive of Republic of Karelia.

УДК 94(47).084.3+94(47).084.5

Статья поступила в редакцию 05.01.2018

\section{ФОРМИРОВАНИЕ НОВОГО БЫТА МОЛОДЕЖИ В 1920-Е ГОДЫ}

(C) 2018

\author{
Шмелёв Сергей Анатольевич, научный сотрудник музея авиации и космонавтики \\ Самарский наџиональный исследовательский университет имени академика С.П. Королёва
} (2. Самара, Российская Федераџия)

\footnotetext{
Аннотация. В данной статье рассматривается проблема формирования нового быта молодежи в 1920-е гг., имевшая большое значение в работе партии большевиков по коммунистическому воспитанию молодого поколения. Формирование нового быта молодежи имело свои особенности и было направлено на преодоление традиционных форм индивидуалистического быта, воспитание коммунистического мировоззрения, развитие коллективных форм взаимоотношений среди подрастающего поколения, вовлечение молодежи в борьбу с религиозными и другими бытовыми пережитками. Партия стремилась установить контроль и руководить молодежью через комсомольские организации. В работе комсомола отразились все противоречия, присущие переходной эпохе 1920-х годов. В статье на конкретных фактах раскрыты основные формы и методы практической работы по формированию нового быта среди молодежи, направленные на изменение повседневных отношений между юношами и девушками; постановку массовой работы в молодежной среде через клубы, спортивные и танцевальные кружки, кинематограф; мобилизацию молодых людей на борьбу с быто-
} 
выми пережитками; создание новых культурно-бытовых традиций и распространение их через молодежь на общество в целом.

Ключевые слова: комсомол; партия большевиков; новая экономическая политика; борьба за новый быт; «болезни» комсомола; мелкобуржуазная стихия; борьба с мещанством; «упаднические» настроения; бытовые ядра; бытовые коммуны; работа среди девушек; танцы; поведение в быту; физкульткружки; кинематограф.

Формирование нового быта молодежи являлось частью общей задачи партии по коммунистическому воспитанию молодого поколения. В годы революции и Гражданской войны многие молодые люди самоотверженно участвовали в борьбе, беззаветно жертвуя собой. В годы нэпа задача сильно осложнилась. Необходимо было воспитывать молодежь в духе коммунизма в условиях разлагающей мелкобуржуазной среды. Новое поколение партийных рядов должно было стать носителем новых, коллективистских ценностей, проявлять устойчивость к давлению обывательской среды. От решения этой задачи зависела судьба партии, судьба революции.

Идеологическая работа среди молодежи велась через Российский коммунистический союз молодежи под руководством партии. Результативность этой работы во многом зависела от того, насколько эффективно комсомольцы могли противостоять тем негативным явлениям, которые неизбежно возникали в работе их организаций в условиях новой экономической политики. Однако, как показала дальнейшая работа, «в руководящих органах комсомола начали проявляться трения, элементы так называемого юношеского синдикализма, обособления РКСМ от советских, профессиональных и других организаций» [1, с. 316].

12 декабря 1920 г. ЦК РКП(б) разослал всем губернским и уездным комитетам партии письмо о работе РКСМ. Как указывалось в письме, III съезд РКСМ показал, что комсомол переживает кризис. Этот кризис выражался «в несоответствии между количественным ростом членов союза и уровнем сознательности их, в сильном уменьшении и ухудшении кадра активных работников РКСМ и в падении дисциплины в юношеских организациях» [1, с. 316]. В результате кризис ослабил способность комсомола участвовать в строительстве Советской республики. ЦК РКП(б) призвал парторганизации оказать помощь комсомольским организациям и направить в них молодых коммунистов. Основная задача момента заключалась в «распространении политического сознания среди членов союза», оказании помощи в проведении политических кампаний, налаживании работы клубов, снабжении литературой [1, с. 318].

Работа комсомольских организаций осложнялась тем, что, как отметил ХІ съезд РКП(б), состоявшийся 27 марта - 2 апреля 1922 г., «объектом массовой работы РКСМ является совершенно новый слой пролетарской молодежи, выросший в эпоху революции, не испытавший на себе гнета капиталистического строя, подвергающийся сейчас, в связи с новой экономической политикой, деклассированию, распылению и переживающий резкое ухудшение своего экономического положения (массовое увольнение с производства, уменьшение заработка, срыв норм охраны труда и т.д.)» $[1$, с. 521]. Съезд обратил внимание на бытовые угрозы: «Усиление мелкобуржуазной стихии оказывает особенно разлагающее влияние на рабо- чую молодежь. Ее сопротивляемость этим влияниям (в особенности бытовым) чрезвычайно слаба, что вместе с ухудшением экономического положения рабочей молодежи понижает в ее среде интерес к общественно-политической жизни» [1, с. 521]. Учитывая эти моменты, съезд указал: «...РКСМ должен противопоставить разлагающему влиянию мелкобуржуазной стихии (кино, бульварная литература и т.д.) свою энергичную работу, приспособленную к запросам молодежи» [1, с. 521]. Съезд поставил перед РКСМ главную задачу: «пропитать всю воспитательную работу союза элементами марксизма, широко развить культурно-воспитательную работу и приспособить ее к психологическим особенностям возрастных групп» [1, с. 522].

Вопросы воспитания нового бытового поведения молодежи были связаны с формированием социалистической культуры потребления и борьбой с мещанскими ценностями. В связи с этим в своем выступлении на $\mathrm{V}$ Всесоюзной конференции ВЛКСМ (24-31 марта 1927 г.) первый секретарь ЦК ВЛКСМ Н.П. Чаплин отметил, что «строительство нового культурного быта нашей молодежи» является одним из основных участков работы [2, с. 29].

Как и в случае с партией, для комсомольских организаций были характерны следующие «болезни»: пьянство, половая распущенность, «упаднические» настроения, обывательские интересы и пр. В целях преодоления этих явлений были созданы конфликтные комиссии при комитетах комсомола [3, л. 114]. «Положение о местных конфликтных комиссиях» было утверждено приказом № 4 Бюро ЦК ВЛКСМ от 28.04.1926 г. [4, л. 180]. Задача конфликтных комиссий состояла в изучении «болезненных явлений в жизни организации» и разработке мер, «направленных к предупреждению их и изжитию».

Учитывая эти «болезненные явления», практическая работа по формированию нового быта среди молодежи была направлена на решение следующих основных задач: 1) борьба с мещанством в бытовой жизни; 2) изменение повседневных отношений между юношами и девушками; 3) вовлечение молодежи в массовую общественную работу через клубы, спортивные, технические, военные и другие кружки; 4) борьба с религиозными пережитками в быту; 5) создание новых культурно-бытовых традиций.

Работа по формированию нового быта молодежи предусматривала повышение образовательного, культурного уровня; вовлечение молодежи в работу по созданию коллективных форм организации быта, например бытовых коммун, бытовых ядер; коллективное посещения кино, театров; проведение безалкогольных вечеринок; организацию клубной работы, физкульткружков; привлечение девушек в работу комсомольских организаций; участие в антирелигиозных кампаниях и т.д.

В 1920-е годы возникла такая форма организации коллективного быта, как бытовые коммуны. Они возникали по инициативе молодых людей, решив- 
ших вести совместный быт. Анализ показывает, что молодые люди решали объединяться в бытовые коммуны не столько из-за желания воплотить в жизнь коммунистические идеалы, сколько из-за чрезвычайной нужды. Например, в Ленинграде несколько комсомолок завода «Стенька Разин» жили в ужасных условиях. «С помощью КСМ они добились от фабзавкома небольшой квартиры, оборудовали ее и начали жить коммуной. Несколько ребят завода «Красный путиловец» также решили начать жить коммуной. Нашли помещение, установили образцовый порядок». В Днепропетровске ребята также организовали коммуну [5, л. 27].

В Самаре первая бытовая коммуна была организована при заводе № 42. Помещение коммуны состояло из трех комнат, где разместили 6-7 коек, стол и несколько стульев. В коммуне было девять комсомольцев и мать одного подростка, которые «сжились в крепкую, дружную семью». Молодежь завода решила поставить в пользу коммуны клубный вечер. Зарплата ребят составляла 20-30 рублей. Каждый член коммуны отдавал 13 рублей на питание. Хозяйством занималась мать коммунара. Она готовила, убирала. Ей помогали четыре девушки. Коммуна выписывала 3 газеты и 2 журнала. Ребята и девушки коллективно посещали кино и театр. Как сообщалось в отчете, настроение у всех было хорошее, всем были довольны [6, л. 106]. Однако внешне благополучная жизнь коммуны никого не вводила в заблуждение, поскольку было понятно, что эта форма жизни не могла конкурировать с традиционным семейным укладом.

Одной из перспективных форм работы среди молодежи считались бытовые ядра. Они возникли в Ленинграде, когда на фабрике «Красный швейник» сформировалась «группа ребят, желающих работать по быту. Начали с того, что стали распространять литературу по вопросам быта, потом собрались группой актива и пошли в кино, после чего в воскресенье собрались поговорить по душам. И теперь коллективное хождение в театр, кино, читка Ленина по воскресеньям - стало обычным явлением». На фабрике имени Петра Анисимова ядро организовало в дни получки коллективные посещения кино и театров, чтобы побороть хулиганство и пьянство [5, л. 29].

В обзоре по материалам информационного подотдела ЦК ВЛКСМ от 15.06.1927 г. «Массовая культурная работа среди рабочей молодежи вне стен клуба» говорилось: бытовые ядра «возникают на основе добровольного объединения масс молодежи и комсомольцев, вокруг конкретного, всех интересующего дела». «Круг вопросов, над разрешением которых работают группы, чрезвычайно велик. Группы организуют экскурсии, коллективное хождение в кино, в театры, читки газет, бытовой литературы, устраивают всевозможные вечера самодеятельности, конкурсы, обследование жизни и быта молодежи и т.д.» [6, c. 107].

В Самаре три цеховых ячейки трампарка создали бытовое ядро, в которое входило 24 человека. Ядро взяло шефство над общежитием рабочей молодежи, где проживали 36 человек - бывшие беспризорники. Купили шахматы, шашки, доставили книги из библиотеки. Ядро также обследовало детские ясли трампарка и выявило ухудшение питания и надзора за детьми [6, л. 108].

На V Всесоюзной конференции ВЛКСМ (2431 марта 1927 г.) отмечался положительный опыт работы бытовых ядер: «Эти ядра ставят перед собой маленькие конкретные задачи, изучают тот или иной вопрос быта, разрабатывают отдельные конкретные мероприятия и доводят их до конца» [2, с. 301]. Недостатком работы бытовых ядер было то, что они «в своей работе не вышли еще за пределы организации мелочей быта и досуга молодежи». «Часто работа бытовой группы после организации вечера самодеятельности, конкурса и т.д. замирает. Ребята не знают, как дальше работать, что также обусловлено недостаточным руководством работой групп со стороны ячеек и комитетов союза». Обращалось внимание также на то, что «бытовые ядра и группы широко развиваются только в Ленинграде. В других организациях они возникают медленно» [7, л. 40].

В целом можно признать, что бытовые ядра и группы, возникшие как форма самоорганизации молодежи, сыграли положительную роль в формировании новых практик бытового поведения, хотя в дальнейшем и не получили своего развития.

Наиболее сложным направлением в работе комсомола была работа среди девушек. Она была выделена в отдельное направление, поскольку этого требовал «особый подход в силу культурно-бытовых и экономических условий», которые определяли положение женщины вообще [8, с. 28].

Работа комсомола среди девушек имела свои особенности. Если женотделы вели борьбу за фактическое равенство, предполагавшее равноправное положение работницы на производстве, освобождение ее от домашнего хозяйства и воспитания детей, то наиболее острым вопросом в комсомольских организациях был вопрос о «нетоварищеском» отношении юношей к девушкам. Общую проблему взаимоотношений между юношами и девушками одна комсомолка охарактеризовала так: «К девушкам ребята относятся по-скотски: попытался подделаться, ничего не выходит, значит, начинается травля. Нередко девчата плачут от больно уж "вежливого" обращения с ними» [9, с. 29].

В протоколе от 29.12.1923 г. 11-й Самарской городской конференции РКСМ говорилось: «Работа среди девушек проходит под крышкой интимных связей. Если девушка хорошая на рожицу, ее принимают в союз, если нет, то не принимают» [10, л. 1].

Вопрос об использовании «интимных» отношений как способе вербовки девушек в комсомол обсуждался 13 мая 1924 г. на совещании девушек-комсомолок Самарской уездной организации делегаток 9-го уездного съезда РКСМ, где говорилось: «Совещание категорически протестует против метода интимной связи комсомольцев с несоюзными девушками, ибо он показал, насколько он не жизненен и допускать его следует лишь в тех случаях, если ячейка находит, что товарищ, завязавший связь, вполне выдержан и не оступится на полпути, не подпадет под влияние девушки». Совещание постановило: «Поцелуйчики и обнимания по углам также должны быть изжиты, ибо все это доводит до того, что отталкивает девушек от комсомола» $[11$, л. 5]. 
Зафиксирован также следующий факт, имевший место в Златоусте: «В местном педтехникуме организовалось общество "Долой невинность" - сокращенно "О.Д.Н." Инициатором и вдохновителем организации явился Худяков - бывший секретарь горрайкома РЛКСМ. Задачей общества являлось вовлечение и обработка девушек в направлении "Долой невинность"» [12, л. 119].

В Самарской газете «Голос молодежи» от 4 июля 1924 г. была помещена заметка корреспондентки, назвавшейся Валей, о необходимости осторожного, деликатного подхода к беспартийным девушкам: «Практический метод вовлечения девушки в комсомол - это умелый индивидуальный подход. Беспартийная девушка придает значение поведению комсомольца в кругу девушек. Малейшее нахальное задевание девушки, глупое подмигивание глазами больно укалывают девушку, как бы напоминая ей о кошмарном прошлом, которого еще не совсем изжили и мы. Эти выходки не дают возможности рисовать перед беспартийной девушкой настоящей картины комсомольской организации. С беспартийной девушкой особенно нужно воздерживаться от "братско-товарищеских" выходок, которые характеризуют комсомольскую массу с нелестно-плохой стороны. Чтобы вовлечь девушку в комсомол, необходимо прежде всего комсомольцам воздерживаться от развязности, так как беспартийная еще не понимает комсомольской простоты и приписывает все это хулиганству» [13].

VI съезд РЛКСМ， состоявшийся 12-18 июля 1924 г., постановил: «Ячейка союза должна усилить работу среди девушек, устраняя ненормальности во взаимоотношениях юношей с девушками, вовлекая девушек в работу, всемерно содействуя их самообразованию и выдвижению» [8, с. 28].

В соответствии с Положением о работе среди девушек 1924 г. работа строилась по следующим направлениям: 1) ликвидация неграмотности; 2) вовлечение в кружки физкультуры; 3) вовлечение в профессионально-технические учебные заведения; 4) вовлечение в клубную работу; 5) вовлечение в массовые кампании; 6) ликвидация политнеграмотности $[11$, л. 1].

Однако изменить конфликтную, напряженную ситуацию в отношениях между юношами и девушками не удавалось на протяжении всего периода 1920-х годов. Так, в марте 1928 г. «Коммуна» опубликовал статью, в которой рассказывалось о «войне полов» в Самарском педагогическом техникуме [14]. Педтехникум в Самаре называли в шутку «институтом благородных девиц». В его общежитии шла «война»: «Девушки и парни - вот две воющие стороны. Они смотрят с презрением и злобой друг на друга», - писал Лев Либензон в статье «О пудре и жизни во всех видах». На комсомольских собраниях были случаи, когда девушки срывали предложения только потому, что их вносили парни [14].

Общий культурный уровень молодых людей оценивался крайне низко и отражал интересы типичной обывательской среды. Молодежь в общежитии педтехникума читала «Тайны Парижа». Ни одного номера «Комсомольской правды» не было. Распространенным увлечением среди девушек было гадание на картах. Два раза в неделю в общежитии устраивались танцевальные вечера. Девушки проявляли интерес к знакомствам с нэпманами и высокооплачиваемыми служащими. После обучения в педтехникуме студенты не желали ехать в деревню и работать там в школе. Все эти факты свидетельствовали о доминировании «мелкобуржуазных» интересов среди учащихся и недостаточном внимании со стороны комсомола [14].

В 1920-е годы молодежь, пытаясь по-новому осмыслить отношения между мужчиной и женщиной, устраивала различные обсуждения, диспуты, вечера, посвященные теме любви. Например, на общегородском собрании РЛКСМ Сызранской организации 18 января 1926 г. комсомолец Образцов сделал доклад о быте, где высказал следующее мнение: «О любви: у нас говорили: или нельзя любить, или можно. Вопрос не выяснен. Мы привыкли, если гулять, так уж гулять, а если нет, так совсем нет. Какая бы молодежь ни была - партийная ли, беспартийная, она любить способна, но не нужно увлекаться» [15, л. 27]. Выступавший Кремин категорично заявил, что «нужно каждому комсомольцу заняться работой, тогда у него не будет чувства любви. Любовь - это мещанское чувство. В жизни рабочих вы не увидите романов, им заниматься любовью некогда. Когда комсомольцы будут нагружены, они не будут мечтать о любви». Более вдумчиво подошел к этому вопросу Соколов: «Ребята и девчата из служащих ухаживают один за другой и т.п., любезности можем видеть. В среде рабочих мы видим грубое обращение. Из этого видно, что у нас здесь не все здорово. Нам нужно выяснить чувство любви. Так или иначе, оно у нас есть» $[15$, л. 29].

Много споров порождал вопрос о выборе жены комсомольцами. В отчете Ульяновского губкома комсомола «О работе среди женской молодежи» обращалось внимание на то, что «в практике заметно, что активисты-комсомольцы на комсомолках женятся мало, проповедуя среди них свободную любовь (конечно, это не массово)». Парни открыто признавались: «Женясь на комсомолке, потеряем многое, придешь, а она на собрании (говорят они). Устанешь и хорошо себя чувствуешь, когда жена тебя ждет и уют. А отсюда боязнь у некоторых девушек идти в комсомол - "замуж не выйдешь, да и уважения к тебе меньше"» [16, л. 138].

Большой проблемой было также то, что активные комсомолки, выходя замуж, бросали работу и отрывались от комсомола. Комсомольские организации проявляли недостаточно внимания к замужним комсомолкам, давали задания, не учитывая их семейного положения. В этом состояла еще одна недоработка комсомольских ячеек. Ячейка должна была «помочь самим девушкам и особенно девушкам работницам изжить мещанские черточки в быту, перестать относится к себе, как к придатку мужчины. Надо помочь комсомолке воспитать в себе необходимые качества новой женщины - человека, борца за великое социалистическое будущее нашей страны» [17, с. 16].

Однако, несмотря на все трудности семейного быта, был и положительный опыт создания комсомольских семей. Например, Юлия Васильевна Табарданова (1898 г.р.) вспоминала, как вступила в комсомол в 1923 г. и вышла замуж за комсомольца, 
который в дальнейшем оказывал ей помощь в работе среди женщин. Например, будучи председателем завкома завода им. Володарского, муж помогал ей, как члену бюро комсомола, устраивать на работу «многосемейных» женщин, «укрощать пьяных мужей» $[18$, л. 3-4].

В 1920-е годы большое значение в деле воспитания молодежи и освоения новых форм проведения досуга придавалось развитию физкультуры. На XII съезде партии говорилось: «На фабриках и заводах следует объединить рабочую молодежь в кружки физической культуры» [19, с. 128].

Несмотря на материальные трудности и дефицит кадров, физкультурное движение развивалось. Так, в октябре 1919 г. в Самаре инспектором губотдела спорта и допризывной подготовки Самгубвоенкомата Н.А. Виноградовым, совместно с врачами Самгубздрава А.В. Ливеровским, Португаловым и Гусыниным, был создан Самарский губотдел физкультуры. При совете работал гимнастический зал, в котором занимались 500 детей из детских домов и школ. В нем работали 10 инструкторов. Весной 1920 года были открыты курсы по подготовке инструкторов. В Самаре появились три центральных городских секции: 1) легкоатлетическая, 2) тяжелоатлетическая, 3) подвижных игр (футбол, баскетбол, лаун-теннис). В 1923 г. в Самаре было зарегистрировано 14 спортячеек, в которых занималось примерно 500-600 человек $[20$, л. 2, 5, 6]. В 1923 г. на Трубочном заводе в Самаре была сформирована спортивная ячейка, в которую входило 40 человек. Всего в то время в Самаре спортивные секции насчитывали свыше 500 человек, из которых $30 \%$ составляли беспартийные и $70 \%$ - комсомольцы. Одним из существенных недостатков было слабое руководство спортивной работой. Не хватало специалистов. Однако, несмотря на это, спортивная жизнь в городе активизировалась. Так, с 9 по 12 сентября 1923 г. в Самаре прошла губернская комсомольская олимпиада, в которой приняло участие 143 человека [21, л. 41].

В 1923 г. в Самаре количество спорткружков выросло с 4 до 9. Зимой было проведено 3 соревнования по зимним видам спорта (лыжи, коньки). Летом - 4 - по плаванию и гребле, 6 соревнований по легкой атлетике (бег, прыжки, метание). Проведен чемпионат по французской борьбе, организована кругосветка по Волге. Подводя итоги работы спортсекции губкоммола за 1923 г., завсекцией Гарцер отметил: «Спорт в Самаре стал прежде всего комсомольским» [20, л. 2].

Вопросы развития спорта среди молодежи обсудил 7-й Самарский губернский съезд РКСМ, проходивший 6 июня 1924 г. Съезд отметил ряд недостатков, указав, что актив не втянут в спорт, отсутствует программно-методическое руководство, отсутствует «организация форм спортработы». На съезде прозвучало предложение о необходимости создания массовых спорткружков на предприятиях, в школах, учреждениях, об организации спортивного просвещения, позволяющего получить информацию об основах гигиены, анатомии, физиологии. Выступавшие комсомольцы говорили о необходимости проведения соревнований не для «показания целей, а для собственного усовершенствования и предотвращении заболеваний» [22, л. 68].
Активная работа развернулась и в других губерниях. Например, в Пензе в 1922-1923 гг. при губкомах РЛКСМ были созданы Губбюро, спорткомитеты «Муравей», «Красный молодняк», «Спартак» и другие организации. В работу включились профсоюзы, наробраз и здравоохранение. Был создан межведомственный орган - Совет физической культуры. Все частные спортобщества были ликвидированы. Однако все еще сохранялся «несерьезный взгляд» на физкультуру. Не хватало квалифицированных кадров [23, л. 157].

Одним из наиболее спорных и наиболее популярных видов развлечений молодежи были танцы. В одном из выступлений на V Всесоюзной конференции ВЛКСМ (24-31 марта 1927 г.) говорилось: «Сейчас наблюдается какой-то угар, какая-то танцевальная стихия! ... Танцы кое у кого стали основным средством привлечения молодежи» [2, с. 136]. Эта «танцевальная стихия» больше всего пугала партийнокомсомольское руководство, поскольку, как считалось, угрожала разложением рядов молодежи.

На VIII Всесоюзном съезде ВЛКСМ (5-16 мая 1928 г.) в своем докладе Н.П. Чаплин отметил: «Интересный факт рассказывал один товарищ: в Ленинграде есть частные "танц-классы" (голос: очень много). Интересно значение этих танц-классов с точки зрения разложения рядов молодежи. Оно заключается в том, что девчата-работницы идут учиться танцам, а их там затягивают в омут разврата, в совершенно чуждую нам среду, где они разлагаются» [24, c. 72].

Клубы во многом не смогли противостоять давлению молодежной среды, не имели материальной возможности и не стремились отказываться от развлекательного «уклона». Молодежь хотела танцевать. Комсомольские вожаки вынужденно с этим соглашались, но требовали, чтобы танцы были «без кривляний».

Эту сложную задачу взялась решить секция по пляске НТК ВСФК (Научно-Технический Комитет Высшего Совета по Физической Культуре) [25]. Пленум НТК ВСФК от 18.07.1925 г. утвердил Временное положение о пляске и танцах в клубах, как факторе физического воспитания. В общественной жизни танец должен был стать одним из методов «объединения отдельных членов коллектива и способов эстетического воспитания». Положение рассматривало танцы с точки зрения биологического, социального значения, воспитания ритма, связи с сексуальностью, условий использования в общественной жизни [25, л. 53]. В его вводной части говорилось: «Учитывая необходимость воздействия на кадры трудящихся, еще не вовлеченных в планомерную физкультурную работу, Президиум ВСФК полагает желательным использовать для этой цели ... широко и стихийно практикующиеся пляски и танцы, которые в своих современных формах не редко содержат нежелательные элементы, но будучи регламентированы, должны стать одним из необходимых средств физкультуры». Регламентация должна коснуться «видов движений», «создаваемым под влиянием условий нового революционного быта». Большое внимание уделялось «идеологическому значению плясок и танцев». Пляски и танцы должны 
были способствовать «телесному развитию, укреплению мышц и внутренних органов, а также выносливости, ловкости и овладению всем организмом». Предлагалось культивировать те танцы, которые «дают наилучший биологический эффект» [25, л. 51].

16 апреля 1927 г. секция по пляске НТК ВСФК рассмотрела следующие пожелания Пленума Совета физической культуры: разработка вопроса о различии «комплексных движений для мужчин и женщин в парных танцах», «разработка вопроса о красивых движениях и отражение на них социально-бытовых, трудовых, национальных особенностей», регламентирование «гигиенических условий, в которых должны производиться танцы в клубах», «использование для клубных танцев народных мелодий и народных инструментов» $[25$, л. 24]. Секция провела «обследование танцев» по четырем направлениям: физиологическом, психологическом, хореографическом, социологическом. В результате было принято решение организовать лабораторию по изучению и созданию коллективных плясок. Лаборатория должна была работать при ГЦИФК (государственный центральный институт физической культуры) [25, л. 23]. Функции лаборатории состояли в следующем: а) «разработка коллективных танцев, поступающих по преимуществу извне», б) проработка вопроса о пригодности применения тех или иных танцев, в) создание физкультурных танцев, г) разработка танцев «под углом зрения применения их в клубе и школе» [25, л. 22].

ЦК ВЛКСМ предложил «ряду режиссеров создать цикл новых танцев путем непосредственной работы с клубной массой» [25, л. 20]. Секция в свою очередь предложила «перейти на опытно-исследовательскую работу путем организации соответствующих ячеек по изучению пляски в различных клубах, подобные ячейки, с одной стороны, дадут возможность секции проводить научно-исследовательскую работу, а с другой, будут представлять из себя показательные группы для насаждения в массах правильно-организованных плясок» [25, л. 19].

Опыт по «организации» танцев и плясок показал, что установление целенаправленного контроля и их регламентирование невозможны. В условиях тоталитарного государства эта была небольшая сфера личной свободы, где молодые люди могли вести себя так, как им нравится, и они с большим энтузиазмом отстаивали это свое право на танцплощадках.

Еще одной массовой формой работы с молодежью был кинематограф. Перед кинематографом ставилась сложная задача: с одной стороны, кино должно было быть средством партийной агитации и пропаганды, с другой стороны, кино должно было оставаться средством развлечения молодежи [26, л. 10]. Основным требованием к кино было создание «художественной и идеологически выдержанной ленты», без мещанских предрассудков и контрреволюционных мыслей $[26$, л. 9]. С учетом этого в плане работы кинокомиссии при Политпросвете ЦК на ноябрь, декабрь 1924 г. и январь 1925 г. был намечен выпуск кинолент, посвященных участию комсомола в гражданской войне и подпольной работе [27, л. 29].

С середины 1920-х годов наряду с героической тематикой в кинематографе появляется тема быта молодежи. На заседании кинокомиссии ЦК Союза с представителями комсомольских организаций, киноработников об участии комсомола в работе кино (1925 г.) были названы четыре направления работы кинематографа: 1) создание исторических картин о борьбе молодежи в гражданскую войну; 2) борьба молодежи на Западе; 3) быт рабочей молодежи; 4) создание кино для детей. Высказывалось пожелание о том, что «было бы очень хорошо изобразить в комическом виде некоторые отдельные стороны нашего быта» [26, л. 5, 6].

Однако снять бытовую комедию оказалось сложнее всего. Проблема заключалась в том, что ирония по отношению к положительному герою не допускалась: «У нас все герои нашей страны - красноармеец, рабочий, комсомолец - они в картине должны быть положительными типами, и наши органы не допускают никакого иронического к ним отношения. Это, конечно, сильно стесняет процесс художественного творчества» [26, л. 17].

Не были определены подходы к теме «Комсомол в жизни». Никто не знал, как изображать, кого изображать, что допустимо, что недопустимо снимать [26, л. 44]. Ясно было одно, что «комсомольца нельзя выводить в смешном виде, так же как и коммуниста, рабочего, красноармейца или чекиста». В показе бытовых сцен среди кинематографистов считалось недопустимым изображение любовных интриг героев. Любовные сцены, снятые в соответствии с идеологическими установками, получались карикатурными и антихудожественными: «Когда в картине, предназначенной для деревни, тема о любви подается в таком виде, что красноармеец с любимой девушкой читает "Империализм как новейший этап капитализма", - тоже смеяться будут, а в конце картины они берутся за руки и поют Интернационал» [26, л. 18].

Экранные образы получались надуманными, и зритель сразу же отмечал их фальшивость. Например, в картине «Лицом к лицу» обращал на себя внимание «красноармеец-отпускник, который вернувшись в прекрасно сшитой шинели, ходит по 5 верст и ни капельки пота, все такой же красавец и проходит так всю картину» [26, л. 16]. По поводу такого неудачного изображения комсомольцев говорилось, что «если комсомолец и выведен в какойнибудь картине, то он написан по тезисам, добродетельным, смелым, находчивым, настоящий паинька, если не бог. Вот это-то писание по тезисам - есть одна из основных причин того, что картины наши выходят скверными, плохо написанными и плохо смотримыми» [26, л. 30]. В итоге предлагалось прекратить «канонизировать комсомольцев» и делать из них «живых мощей» [26, л. 32].

По мнению кинокритиков, продукция Совкино была крайне низкого качества. Единственный фильм, получивший признание, был фильм «Красные дьяволята» [26, л. 12]. В остальном было признано, что «советские картины очень плохи, критикуют их во всех углах», что «в советском кинематографе на 99\% преобладает халтура» [26, л. 11, 13]. Критике подвергали даже картины, посвященные Гражданской войне, поскольку они снимались по шаблону: «генералы, развратницы, а со стороны рабочих - чекисты и т.д.», еще «умный и находчивый комсомолец» [26, л. 14]. 
По признанию кинематографистов, «кино может служить центральным проводом в отношении работы между всеми социально-бытовыми явлениями в отношении хулиганства и прочих существующих недостатков» [26, л. 21]. Однако работа кинематографа зачастую давала обратный результат. Проблема заключалась в коммерциализации кино и стремлении кинопроката заработать на авантюрно-приключенческих и мелодраматических фильмах, мелкобуржуазное содержание которых не соответствовало задачам формирования коммунистического мировоззрения молодежи.

Подводя итог, можно сделать вывод, что борьба за новый быт среди молодежи в условиях нэпа отражала все трудности и противоречия переходного периода, сочетавшего элементы социализма и капитализма. Такая двойственная среда не способствовала выработке устойчивого мировоззрения молодежи, блуждавшей между абстракциями марксизма и соблазнами нэпа. Оказавшись в условиях переломного периода становления новой жизни, молодые люди пытались найти новые ответы на традиционные вопросы: что важнее - личные интересы или общественные, какими должны быть отношения между юношами и девушками, как перестроить отношения с родителями - носителями пережитков прошлого, какими должны быть одежда, прическа, можно ли комсомолкам пользоваться косметикой и т.д.

Молодое поколение 1920-х годов, выросшее в постреволюционную эпоху, пыталось строить жизнь по-своему, стремясь разрешить противоречия между старыми традициями и новыми требованиями, демонстрировало и умелое приспособление к «двойным стандартам» для решения своих личных жизненных задач, и жертвенный отказ от всего личного ради достижения «светлого будущего».

\section{Список литературы:}

1. КПСС в резолюциях и решениях съездов, конференций и пленумов ЦК (1898-1986). М.: Политиздат. 1983. Т. 2. 606 с.

2. Российский государственный архив социальнополитической истории (РГАСПИ). Ф. М-37. ОП. 5. Д. 10. V Всесоюзная конференция ВЛКСМ 24-31 ма- рта 1927 г. Стенографический отчет. Молодая гвардия. Москва. Ленинград. 1927 г. 440 с.

3. РГАСПИ. Ф. М-1. ОП. 23. Д. 495.

4. РГАСПИ. Ф. 613. ОП. 1. Д. 45.

5. РГАСПИ. Ф. М-1. ОП. 23. Д. 584.

6. РГАСПИ. Ф. М-1. ОП. 23. Д. 859.

7. РГАСПИ. Ф. М-1. ОП. 23. Д. 740.

8. Багаратян Т. Комсомол и работа среди девушек // Коммунистка. 1925. № 10. С. 28-32.

9. Кириллов С. Девушка в комсомоле // Коммунистка. 1928. № 9. С. 27-32.

10. Самарский областной государственный архив социально-политической истории (СОГАСПИ). Ф. 53.

Оп. 1. Д. 403.

11. СОГАСПИ. Ф. 53. Оп. 1. Д. 418.

12. РГАСПИ. Ф. М-1. ОП. 23. Д. 580.

13. Вопросы комсомольской работы. О девушках // Голос Молодежи. 04.07.1924. № 94. С. 4.

14. Либензон Л. О пудре и жизни во всех ее видах // Коммуна. 02.03.1928. № 53 (2764). С. 2.

15. Государственный архив новейшей истории Ульяновской области (ГАНИУО). Ф. 43. Оп. 1. Д. 272.

16. ГАНИУО. Ф. 1. Оп. 1. Д. 1487.

17. Смидович С. Изжить болезненные явления в комсомоле // Коммунистка. 1929. № 16. С. 11-16.

18. ГАНИУО. Ф. 57а. Оп. 2. Д. 125. Табарданова Ю.В. Воспоминания о работе на Машиностроительном заводе в первые годы Советской власти. Рукопись.

19. КПСС в резолюциях и решениях съездов, конференций и пленумов ЦК (1898-1986). М.: Политиздат. 1983. Т. 3.606 с.

20. СОГАСПИ. Ф. 53. ОП. 1. Д. 345.

21. СОГАСПИ. Ф. 53. ОП. 1. Д. 281.

22. СОГАСПИ. Ф. 1. Оп. 1. Д. 1386.

23. Государственный архив Пензенской области (ГАПО). Ф. 39. ОП. 1. Д. 16.

24. РГАСПИ. Ф. М-6. ОП. 8. Д. 10. VIII съезд ВЛКСМ 5-16 мая 1928 г. Стенографический отчет. Изд. Молодая гвардия. 1928 г. 602 с.

25. Государственный архив Российской Федерации (ГАРФ). Ф. Р-7576. Оп. 3 Д. 4.

26. РГАСПИ. Ф. М-1. ОП. 5. Д. 9.

27. РГАСПИ. Ф. М-1. ОП. 23. Д. 389.

\section{CREATING A NEW WAY OF LIFE FOR THE YOUTH IN THE 1920S}

(C) 2018

Shmelev Sergey Anatolyevich, researcher of Aviation and Cosmonautics Museum Samara National Research University (Samara, Russian Federation)

Abstract. This paper deals with the problem of creating a new way of life for young people in the 1920s, which was of great importance in the work of the Bolshevik Party for the communist education of the younger generation. Creating a new way of life of the youth had its own peculiarities and was aimed at overcoming the traditional forms of individualistic way of life, educating the communist worldview, developing collective forms of relationships among the younger generation, involving young people in the struggle against religious and other everyday remnants. The party sought to establish control and manage youth through Komsomol organizations. The work of the Komsomol reflected all the contradictions inherent in the transitional era of the 1920s. The paper contains main forms and methods of practical work that created a new life among young people aimed at changing everyday relationships between young men and girls; it describes mass work for the youth through clubs, sports and dance clubs, cinematography; mobilization of young people to combat domestic remnants; creating new cultural and everyday traditions and their distribution through the youth to society as a whole.

Keywords: komsomol; party of Bolsheviks; new economic policy; struggle for new way of life; «problems» of Komsomol; petty-bourgeois element; struggle against philistinism; «decadent» moods; household core; household communes; work among girls; dancing; behavior in everyday life; physical education; cinema. 